\title{
The Development of Traditional Morality and the Correlative Evolution of Thanatological Apprehension
}

\author{
DePergola II PA* \\ ${ }^{1}$ University of Massachusetts Medical School, Worcester, MA, USA \\ ${ }^{2}$ College of Our Lady of the Elms, Chicopee, MA, USA
}

${ }^{*}$ Corresponding author: DePergola II PA, University of Massachusetts Medical School, Worcester, MA, USA, E-mail: drpeterdepergola@gmail.com

Citation: DePergola II PA (2018) The Development of Traditional Morality and the Correlative Evolution of Thanatological Apprehension. J Health Sci Stud 1(1): 102. doi: 10.15744/2767-9136.1.102

Received Date: August 16, 2018 Accepted Date: May 20, 2019 Published Date: May 22, 2019

\section{Introduction}

\section{Overview}

In his Phenomenology of Spirit, Georg Hegel suggests that to be moral is to act in accordance with the moral tradition of one's own country. ${ }^{1}$ Hence, for Hegel, individuals act morally to the extent that they bear witness to the traditional moral climate in which they are situated. Thus understood, acting morally is a social phenomenon, comprised of attitudinal ebbs and flows that are nuanced by the changing moral traditions with which they inextricably interrelate. This much has proven particularly true with regard to the evolution of western attitudes toward death and [1,2] dying. ${ }^{2}$ Indeed, significant traditional changes from the Middle Ages to the present day have transformed the hidden perceptions of death and dying ("thanatological apprehension") of history into the increasingly rapid and perceptible expressions of [3] today. ${ }^{3}$

Contemporary dialogue over death and dying may richly benefit from an exploration of historical attitudes toward death and dying and the moral traditions from which they developed. In the context of present-day thanatological apprehension, conversations over death and dying are frequently founded upon the philosophical and theological concepts of "respect for life" ${ }^{4,5}$ and "sanctity of life." ${ }^{6}$ Save for the robust language and idiosyncratic premises employed today, these concepts were by no means foreign to historical moral traditions [4-6]. For the Ancients, death was similarly planned, perceived, and approached with respect and dignity. Bathed in ritual comparable to the current age, the old attitude in which death was both familiar and near, evoking no great fear or awe, offers an enormous contrast to the attitude of today, where death is so unbearably frightening that individuals cringe at the mention of its name. ${ }^{7}$

\section{Analytical Method}

An increasingly blurred understanding of the role and value of traditional moral development vis-à-vis contemporary thanatological apprehension suggests a critical need to revisit the relationship shared between changing moral traditions and the correlative evolution of attitudes toward death and dying. To be sure, the issues of immediate import to the conversation over the historical manifestation of thanatological apprehension in light of changing moral traditions is manifold, and any singular analysis of topics, no matter how sweeping, will unavoidably fall short of adequacy. This essay thus aims to briefly address but three: subjective death, objective death, and forbidden death.

The present essay grounds its argument in two, straightforward premises: (i) the historical significance of traditional morality

1. See Gerald Dworkin, The Theory and Practice of Autonomy (New York: Cambridge University Press, 1988), 34.

2. For a concise yet thorough analysis of various western apprehensions of death and dying, see Philippe Ariès, Western Attitudes Toward Death: From the Middle Ages to the Present (Baltimore: The Johns Hopkins University Press, 1974).

3. Ariès, Western Attitudes Toward Death, 1-2.

4. See Owsei Temkin, “The Idea of Respect for Life in the History of Medicine," in Respect for Life in Medicine, Philosophy, and the Law, eds. Owsei Temkin, William K. Frankena, and Sanford H. Hadish (Baltimore: The Johns Hopkins University Press, 1977), 1-23.

5. See William K. Frankena, “The Ethics of Respect for Life," in Respect for Life in Medicine, Philosophy, and the Law, eds. Owsei Temkin, William K. Frankena, and Sanford H. Hadish (Baltimore: The Johns Hopkins University Press, 1977), 24-62.

6. See James F. Keenan, “The Concept of Sanctity of Life and its Use in Contemporary Bioethical Discussion.” In Sanctity of Life and Human Dignity, ed. Kurt Bayertz (Boston: Kluwer Academic Publishers, 1996), 1-18.

7. Ariès, Western Attitudes Toward Death, 3-14. 
informs and directs contemporary thanatological apprehension; and (ii) robust and comprehensive thanatological apprehension exists to the extent that is knowledgeable of traditional moral development and complimentary of the contemporary moral tradition in which it is situated. Drawing from this syllogism, the aim and proposal of this essay is to examine the historical relationship between the development of moral traditions and changing attitudes toward death and with the intention of positing the argument that contemporary thanatological apprehension is both valuable and practical insofar as it is familiar with and honorary of traditional moral development and complimentary of the moral tradition in which it is presently situated.

To secure the justification of this thesis, the current essay will move in three parts. First, it will address "subjective death," including a specific analysis of subjective death in history and the relationship it shares with the ethical notion autonomy, including its limits, vis-à-vis death and dying. Second, it will address "objective death," including a specific analysis of objective death in history and the relationship it shares with the ethical notions of nonmaleficence and beneficence vis-à-vis death and dying. Finally, it will address "forbidden death," including a specific analysis of forbidden death in history and its place in the contemporary American experience vis-à-vis death and dying.

\section{Subjective Death: Autonomy and the History of Death and Dying}

\section{Subjective Death in History}

The eleventh and twelfth centuries were marked by significant alterations in attitudes toward death and dying. This was not a matter of new attitudes replacing those of old, but of subtle modifications which gradually attributed a dramatic and personal meaning to the individual's traditional familiarity with death and dying. This transformation was signified by four phenomena in particular, each of which introduced the individuality - the "subjectivity" - of the dying person into the old idea of the human race en route to a collective destination. For the sake of brevity, this essay will address but two. ${ }^{8}$ The first phenomenon concerns the portrayal ${ }^{9}$ of the Last Judgment at the end of the world. ${ }^{10}$ Keeping with general eschatology, the dead who belonged to the Church and who entrusted their bodies to its care "went to sleep" and were at rest until the Second Coming, when they would awaken in the paradise of heavenly Jerusalem. Individuals would be separated scrupulously according to the metaphorical "balance sheet" of their personal lives, and by it they would be judged. ${ }^{11}$

The second phenomenon concerns the suppression of eschatological time between death and the end of the world, and of the termination of situating the judgment at the time of the Second Coming, relocating it, instead, to the bedchamber - the deathbed. Here, two observations are worthy of note. The first concerns the juxtaposition of the traditional portrayal of death in bed and that of the individual judgment of each life. By the fifteenth and sixteenth centuries, death in bed was a calming, collective rite. ${ }^{12}$ On the other hand, the judgment was unique to each individual, and no one could ascertain the dying individual's fate until the judge had made his decision. ${ }^{13}$ The second observation concerns the increasingly close relationship established between death and the biography of each individual life. By the fourteenth and fifteenth centuries, the dying individual played a significant role in the ceremonies surrounding death. ${ }^{14}$ Since it was believed that the attitude of the dying person at the moment of death would give one's biography its final meaning and conclusion, the way one experienced dying and the circumstances surrounding death thus became of critical moral significance. ${ }^{15}$

\section{Autonomy and its Limits vis-à-vis Death and Dying}

The individual experience of subjective death suggests the moral agent - the dying individual - as necessarily autonomous. This is particularly evident in light of the aforementioned notion of each individual being judged according to one's "balance sheet," comprised of free choices and corresponding moral attitudes. As Gerald Dworkin notes, individuals are morally autonomous insofar as the moral principles they employ are their own. Moral autonomy thus manifests itself to the extent that: (i) individuals are the author and originator of their operative moral principles; (ii) individuals freely choose their moral principles; (iii) individual subjective will is the ultimate authority and source of moral principles; (iv) individuals decide which moral principles to accept as binding; (v) individuals bear responsibility for the moral theory accepted and the corresponding principles applied; and (vi) individuals refuse to accept without independent consideration the judgment of others as to what is morally correct. ${ }^{16}$

8. The third and fourth phenomena concern macabre themes and the interest shown in portrayals of physical decomposition, and the return of funeral inscriptions to a certain personalization of tombs, respectively. See Ariès, Western Attitudes Toward Death, 39-50.

9. The portrait of Christ in Majesty, surrounded by the four Evangelists, is an image inspired by the Apocalypse of John - of Christ returning at the end of the world. See Ariès, Western Attitudes Toward Death, 29-33; see especially p. 29-30.

10. For the precise scriptural reference, see the twenty-fifth chapter of the Gospel of Matthew.

11. In this sense, the idea of the Last Judgment is linked with that of individual biography. See Ariès, Western Attitudes Toward Death, 29 -33; see especially p. 33.

12. No one possessed particular worries about the fate of the dying person. See Ariès, Western Attitudes Toward Death, 33-39; see especially p. 37.

13. In this way, the collective scene of a corrective rite and the anxiety of a personal interrogation mesh. See Ariès, Western Attitudes Toward Death, 33-39; see especially p. 37.

14. Individuals often presided over their dying as if it were an event in the past, determining what ritual was idiosyncratically suitable. See Ariès, Western Attitudes Toward Death, 33-39; see especially p. 38.

15. Ariès, Western Attitudes Toward Death, 33-39.

16. Dworkin, The Theory and Practice of Autonomy, 34-47; see especially pp. 34-35. 
However critical to the phenomenon of subjective death in the fifteenth and sixteenth centuries, the retreat to private morality unavoidably leads to a sort of moral atomism in which each individual's moral beliefs and actions are absolute and unassailable. The traditional notion of ethics as reasoned, communitarian discourse in search of the common good is thereby annihilated. The sense of solidarity that derives from consensus about what is morally appropriate is lost. The experience of subjective death makes clear that individual choice must be regarded highly and respected deeply, and that individuals are ultimately the sum of their actions. However, flight into the isolation of self-rule at the cost of public concern does not eradicate the moral responsibility to subjectively engage in society in the pursuit of some common moral goals that transcend [7] autonomy. ${ }^{17}$ Thus, the biography by which individuals are to be judged is substantiated to the extent that it practices concern for common morality. ${ }^{18}$

\section{Objective Death: Nonmaleficence and Beneficence and the History of Death and Dying}

\section{Objective Death in History}

Beginning with the eighteenth century, western society tended to give death a new meaning. Societies came to exalt and even dramatize death, considering it disquieting and greedy. What now concerned individuals was not with their own death, but "objective death" - the death of the other person. Previously, death in bed was a solemn event, prepared for individually. ${ }^{19}$ However, by the nineteenth century, a new form of passion stirred those who surrounded the deathbed, consumed with grief. Emotion now visibly shook them: they cried, prayed, and gesticulated. Ritual was subsequently stripped of its banal and customary character. Concern for the other - the object of death - now took center stage. The passionate sorrow of separation from the dying ignited passions within both the dying and those who cared for them, transforming the once exclusively subjective deathbed into a communal locale of bereavement. ${ }^{20}$

As noted above, until the eighteenth century, death was a concern for the person threatened by it - for the dying individual alone. Thus, it was up to the person to express idiosyncratic ideas, feelings, and wishes vis-à-vis death. To ensure this, the dying possessed an instrument: a last will and testament. ${ }^{21}$ From the thirteenth to the eighteenth century, the will was the means by which each person made known the decisions required to secure the salvation of the soul and the repose of the body. ${ }^{22}$ Hence, in trusting the next of kin, the dying person delegated to them a part of the powers that had previously been exclusively exercised autonomously. The dying certainly retained their principal and apparent personage in death, but the attitude of those to whom the dying entrusted their care transformed significantly. ${ }^{23}$

\section{Nonmaleficence and Beneficence vis-à-vis Death and Dying}

The communal experience of objective death suggests the duties of nonmaleficence and beneficence required of, and due to, both the dying and those surrounding the deathbed. Nonmaleficence ${ }^{24}$ is frequently described as the primary principle of biomedical ethics, ${ }^{25}$ and it carries particular thanatological weight. Applied in the historical context in question, nonmaleficence has (at least) four practical uses. For the sake of brevity, this essay will address but three. ${ }^{26}$ The first, concerning medicine as a moral enterprise, is the injunction to act only for the benefit of the sufferer - here, for the benefit of both the dying and those surrounding the deathbed. The second use, concerning due care, is the injunction to strive continuously to improve the care, both medical and personal, which is the product of knowledge, compassion, and skill - here, to ensure that both the dying and the grief-stricken avoid harm that might the product of neglecting moral responsibilities. The third use, concerning risk-benefit ratio, is the injunction to avoid any action or event that results in prolonged diminished ability to respond to physical, psychological, or social challenges - here, to preserve the capacities to communicate significant moral emotions. ${ }^{27}$

17. Moreover, the aim of democracy, particularly within the Judeo-Christian tradition, is to advance the cause of community rather than its atomization. See Edmund D. Pellegrino and David C. Thomasma, For the Patient's Good: The Restoration of Beneficence in Health Care (New York: Oxford University Press, 1988), 11-36; see especially p. 22.

18. Pellegrino and Thomasma, For the Patient's Good, 11-36; see especially pp. 21-22.

19. The dying expected it, and when it occurred it was quickly followed by customary ritual, often prepared by the dying individuals themselves. See Ariès, Western Attitudes Toward Death, 55-82; see especially p. 59.

20. Ariès, Western Attitudes Toward Death, 55-82; see especially pp. 55-60.

21. The last will and testament of the nineteenth century was not the dry, legal document it frequently is today. See Ariès, Western Attitudes Toward Death, 55-82; see especially p. 63.

22. These "decisions" included, among other things, the deep thoughts, religious faith, attachment to possessions, and personal loves of the dying. See Ariès, Western Attitudes Toward Death, 55-82; see especially p. 63.

23. Ariès, Western Attitudes Toward Death, 55-82; see especially pp. 63-68.

24. The term "nonmaleficence" is founded on the Hippocratic maxim, primum no nocere: "first, do no harm."

25. For a fine analysis of the place of nonmaleficence in the Hippocratic tradition, see Edmund D. Pellegrino, Humanism and the Physician (Knoxville: The University of Tennessee Press, 1979); see especially Chapter Six.

26. The fourth practical use of nonmaleficence, concerning the benefit-detriment equation, is the injunctive to reason effectively about which behavior will prove most beneficial. In the present context, that is made manifest through double-effect reasoning to determine the morally appropriate course of action for both the dying and the bereaved. See Albert R. Jonsen, "Do No Harm," Annals of Internal Medicine 88 (1978): 827-32; see especially pp. 830-31.

27. Jonsen, "Do No Harm," 827-32; see especially pp. 828-31. 
On the other side of the same coin, beneficence, which carries similar thanatological weight, commands a special kind of relationship at the deathbed that goes beyond passivity and obliges individuals to act in the interest of the other, even at some cost to comfort, power, prestige, or biography. Such a duty to do good is a degree above what is expected by law or the mores of other activities, such as those found within professional relationships. ${ }^{28}$ Applied in the traditional context of the nineteenth century, beneficence offers an invitation to "agapeistic" ethics ${ }^{29}$ - here, the moral responsibility of the dying to "die well" and to support those at the deathbed, and the moral responsibility of the bereaved to help usher in death in a manner that is peaceful, supportive, and comfortable for the dying. ${ }^{30}$

\section{Forbidden Death: The Contemporary American Experience of Death and Dying}

\section{Forbidden Death in History}

As suggested above, the attitude toward death changed from the Middle Ages to the mid nineteenth century, but so slowly that contemporaries hardly noticed. Conversely, in the present day, ${ }^{31}$ attitudes toward death and dying have witnessed a brutal revolution in traditional ideas and feelings. Death, once so omnipresent that it seemed familiar, would become shameful and, eventually, "forbidden." The impetus of this transformation unquestionably lies in a sentiment already expressed during the second half of the nineteenth century: those surrounding the deathbed had a tendency to spare the dying of the details pertaining to the gravity of their terminal condition. ${ }^{32}$ However, this sentiment would rapidly be replaced by another, ${ }^{33}$ one characteristic of modernity: those at the deathbed avoided ${ }^{34}$ the disturbance and the overly potent and unbearable emotion caused by the ugliness of death and its presence in the midst of a happy life. ${ }^{35}$

Between 1930 and 1950, the evolution of thanatological apprehension accelerated notably. This was due to an important physical phenomenon: the displacement of the deathbed. One no longer died at home, surrounded by one's family, but in the hospital, and frequently alone. The hospital had become the place to receive care that could no longer be provided at home. ${ }^{36}$ Death thereby became a technical phenomenon obtained by the termination of care, a cessation determined by a decision of the physician and the hospital team. Hence, the initiative of care passed from the family - today as much an outsider as the dying person - to the physician and the hospital team. ${ }^{37}$ Clinicians had become the new masters of death - of its moment as well as its circumstances and their aim was to secure for the patient an acceptable style of "living while dying." 38

\section{The Contemporary American Experience vis-à-vis Death and Dying}

The modern attitude toward death, composed of the interdiction of death in order to preserve happiness, was born in the United States at the beginning of the twentieth century. ${ }^{39}$ Many factors affect how and where individuals die in the cultural climate of contemporary America. For the sake of brevity, this essay will address but two: access to health care and its costs, and pain management and palliative care. Regarding the former, unlike most industrialized nations, the United States currently has no (active) universal heath care system. Delivery of health care is thus deeply entrenched in the private enterprise [8,9] system. ${ }^{40}$ In 2000, approximately fourteen percent of the American population had no insurance whatsoever. ${ }^{41}$ While most Americans express a desire to die at home, relatively few actually achieve such a death. Hence, the last year of life is exponentially costly, ranging,

28. In the absence of this self-effacement, medicine ceases to be a profession and instead becomes nothing transcendent of a trade or craft. See Pellegrino and Thomasma, For the Patient's Good, 25-27; see especially p. 27.

29. Agapeistic ethics can be understood as moral responsibility founded on love and aimed at living charitably for others. See Pellegrino and Thomasma, For the Patient's Good, 25-27; see especially p. 27.

30. Pellegrino and Thomasma, For the Patient's Good, 25-35; see especially pp. 25-27.

31. This transformation manifests itself in approximately two-thirds of a century. See Ariès, Western Attitudes Toward Death, 85-103; see especially p. 85.

32. One motivation for the breach in veracity was to assume for the sick the burden of their ordeal. See Ariès, Western Attitudes Toward Death, 85-103; see especially p. 86.

33. The origin of the original sentiment concerns the intolerance of another's death and the confidence shown by the dying in those surrounding them. See Ariès, Western Attitudes Toward Death, 85-103; see especially pp. 86-87.

34. Now no longer for the sake of the individual, but for the sake of society and those close to the dying person. See Ariès, Western Attitudes Toward Death, $85-103$; see especially p. 87.

35. Ariès, Western Attitudes Toward Death, 85-103; see especially pp. 85-87.

36. Previously, the hospital had been a shelter for the poor, only later becoming a medical facility where people came to be healed, where one battled death to the end. See Ariès, Western Attitudes Toward Death, 85-103; see especially p. 87.

37. Accordingly, the evidential and passionate sorrow that was once acceptable for the family and friends of the dying does not contemporarily inspire pity but repugnance; it has become morbid. The world may be empty in the absence of the deceased, but no one is permitted to say so aloud. See Ariès, Western Attitudes Toward Death, 85-103; see especially pp. 90-92.

38. Ariès, Western Attitudes Toward Death, 85-103; see especially pp. 87-92.

39. Ariès, Western Attitudes Toward Death, 85-103; see especially pp. 94-103.

40. Expenses are typically paid through third-party payer systems for those who possess insurance. See Janna C. Merrick, "Death and Dying: The American Experience," in End-of-Life Decision Making: A Cross-National Study, eds. Robert H. Blank and Janna C. Merrick (Cambridge, MA: The MIT Press, 2005), 219-241; see especially pp. 219-23.

41. This equates to some 38.7 million persons. See Merrick, “Death and Dying," 219-241; see especially pp. 219-23. 
in $1993-1998$, from $\$ 25,000$ to $\$ 32,000$ per capita. In light of such circumstances, death has become not only physically and emotionally forbidden, but economically hellish as well. ${ }^{42}$

Regarding the latter, there has been much discussion in recent years about the need to improve palliative care in the United States. One area involves its level of quality and ability to adequately manage pain at the end of life. Approximately forty-three percent of Americans will enter nursing homes before death, and more than 1.5 million are currently cared for in nursing homes. Of these patients, ${ }^{43}$ approximately fifteen percent are in persistent pain, and of these, approximately forty-one percent are in severe pain sixty to 180 days later. Moreover, serious questions about palliative care in hospital settings remain. According to the data collected by E. J. Cassel and colleagues, some nonfinancial causes of the undervalued and undeveloped status of palliative care, such as the reluctance of Americans to deal with death, were related to lack of revenue to pay for palliative care in clinical settings. ${ }^{44}$ Furthermore, life-prolonging attempts have a higher reimbursement rate, which some argue leads to more aggressive treatment in futile situations. ${ }^{45}$ Pain management thus continues to prove a major obstacle to the forbidden death of contemporary culture. ${ }^{46}$

\section{Conclusion}

The aim and proposal of this essay has been to examine the historical relationship between the development of moral traditions and changing attitudes toward death and dying and with the intention of positing the argument that contemporary thanatological apprehension is both valuable and practical insofar as it is familiar with and honorary of traditional moral development and complimentary of the moral tradition in which it is presently situated. To secure the justification of this thesis, it has drawn from the from the twofold premises that (i) the historical significance of traditional morality informs and directs contemporary thanatological apprehension; and (ii) robust and comprehensive thanatological apprehension exists to the extent that is knowledgeable of traditional moral development and complimentary of the contemporary moral tradition in which it is situated. To this syllogistic end, the present essay has been successful.

The implications here are significant. To be sure, the increasingly blurred understanding of the role and value of traditional moral development vis-à-vis contemporary thanatological apprehension is a genuine and growing concern. But rather than allowing it to terminate progress, it may instead serve to remind that while the present state of traditional morality vis-à-vis death and dying is important, its situation in history and the manner in which historical developments inform present-day cultural climates is more important still.

\section{References}

1. Ariès P (1974) Western Attitudes Toward Death: From the Middle Ages to the Present. Baltimore: The Johns Hopkins University Press.

2. Dworkin G (1988) The Theory and Practice of Autonomy. New York: Cambridge University Press.

3. Frankena WK (1977) The Ethics of Respect for Life. In Respect for Life in Medicine, Philosophy and the Law, edited by Owsei Temkin, William K. Frankena, and Sanford H Kadish, 24-62. Baltimore: The Johns Hopkins University Press.

4. Jonsen AR (1978) Do No Harm. Ann Int Med 88: 827-32.

5. Keenan JF (1996) The Concept of Sanctity of Life and its Use in Contemporary Bioethical Discussion. In Sanctity of Life and Human Dignity, edited by Kurt Bayertz, 1-18. Boston: Kluwer Academic Publishers, 1996.

6. Temkin, O (1977) The Idea of Respect for Life in the History of Medicine." In Respect for Life in Medicine, Philosophy, and the Law, edited by Owsei Temkin, William KF, Sanford HK, 1-23. Baltimore: The Johns Hopkins University Press.

7. Pellegrino ED, David CT (1988) For the Patient's Good: The Restoration of Beneficence in Health Care. New York: Oxford University Press.

8. Merrick JC (2005) Death and Dying: The American Experience. In End-of-Life Decision Making: A Cross-National Study, edited by Robert H. Black and Janna C. Merrick, 219-41. Cambridge, MA: The MIT Press.

9. Pellegrino ED (1979) Humanism and the Physician. Knoxville: The University of Tennessee Press.

\footnotetext{
42. Merrick, "Death and Dying," 219-41; see especially pp. 219-23.

43. These statistics are derived from a study conducted in 2001. See Merrick, "Death and Dying," 219-41; see especially p. 223.

44. Specifically pinpointed was Medicare payment provisions that encourage hospitals to discharge dying patients quickly. See Merrick, "Death and Dying," $219-41$; see especially p. 224.

45. Merrick, "Death and Dying," 219-41; see especially pp. 223-24.

46. Merrick, "Death and Dying," 219-41; see especially pp. 223-24. See also pp. 233-37.
} 


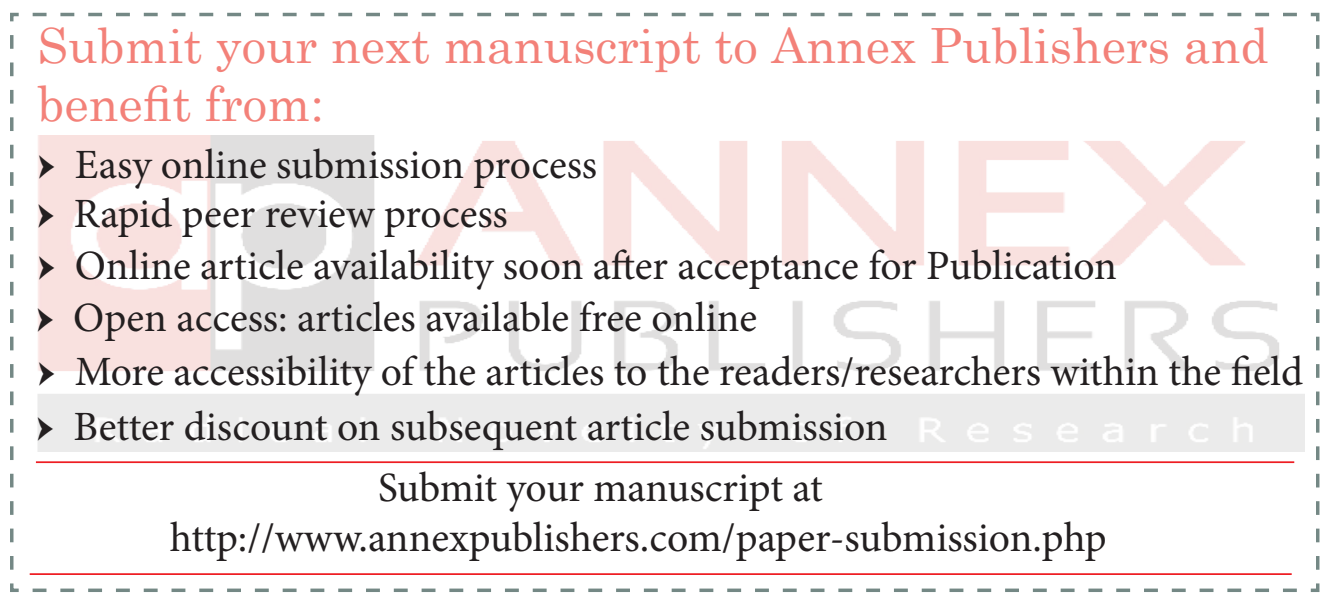

